\title{
CINEMATIC ARCHITECTURE APPROACH IN I\&L HOUSE
}

\author{
${ }^{1}$ Rafii Putra Wedaswara. ${ }^{2}$ Yenny Gunawan, S.T., M.A. \\ ${ }^{1}$ Student in the Bachelor's (S-1) Study Program in Architecture \\ at Parahyangan Catholic University \\ ${ }^{2}$ Senior lecturer in the Bachelor's (S-1) Study Program in Architecture \\ at Parahyangan Catholic University
}

\begin{abstract}
AMI is an architecture movement, lead by 10 young Indonesian architects, is not satisfy with Indonesian architecture scene at that time, which they called "less interesting", "monotone" and "lack of character". AMI is considered to be against of mainstream architecture at that time, identified by having their own idealism, signature, and style. Andra Matin as one of the initiators of the movement, offering a characteristic architecture and not monotonous as the spirit of design direction. Quoting from David Hutama, a curator from architecture media rooang.com, by having a review on Andra Matin design: His works giving an impression of connectedness from one level to another level, making it have an own unique cinematic style caused by an emotional way of aesthetical response through sequence of an user. And many of his works depict minimalist stripes with geometry structure. The goal of this research is to identify a perception of space on one of Andra Matin works, I\&L House.

The methodological research used on this research is a descriptive-qualitative through cimematic architecture approach. Data types that used for an analysis is mental space element, material space, and lived space. The data is obtained from three instrument of gathering data, such as observation, interview, and questionnaire. Analitic technique is built from quantitative analysis and qualitative analysis, from comparing the user analysis report and perceotion data which carried by respondent.

The summary of this research is to define a mental space and material space on the object. The most significant of mental space element and space material giving an influence on shaped space perception such as masculine, directing and exposed, in a lived space element of I\&L house user such as material, shape, light, and sound. In the end, the writer use film as tool for visualizing the summary of this research.
\end{abstract}

Key Words: cinematic architecture, Andra Matin, i\&l house

\section{PENDEKATAN ARSITEKTUR SINEMATIK PADA I\&L HOUSE}

\author{
${ }^{1}$ Rafii Putra Wedaswara. ${ }^{2}$ Yenny Gunawan, S.T., M.A. \\ ${ }^{1}$ Mahasiswa S1 Program Studi Arsitektur Universitas Katolik Parahyangan \\ ${ }^{2}$ Dosen Pembimbing S1 Program Studi Arsitektur Universitas Katolik Parahyangan
}

\begin{abstract}
Abstrak- AMI adalah sebuah gerakan dari 10 arsitek muda Indonesia yang mengkritisi kondisi dunia arsitektur Indonesia pada tahun 1980-an dilihat "tidak menarik', 'monoton', dan 'tidak berkarakter'. Dengan semangat yang bertolak belakang dengan kondisi arsitektur Indonesia pada masa tersebut, AMI membawa idealis, ciri, dan gayanya masing-masing. Andra Matin sebagai salah satu seorang penggagas gerakan tersebut, menawarkan arsitektur yan berkarakter dan tidak monoton sebagai semangat arahan desainnya. Mengutip dari artikel sebuah tulisan oleh David Hutama seorang kurator dan dari media arsitektur rooang.com, mengatakan ruang yang terbentuk dari desain Andra Matin memberikan kesan terhubung antara satu tingkat dengan tingkat lain memiliki sifat cinematik karena desain Andra Matin yang memiliki respon estetis secara emosional melalui sekuensi pengalaman pengamat atau pengguna (User Oriented Design), serta garis minimalis dengan struktur geometris adalah gaya khas dari Andra Matin. Tujuan dari penelitian ini untuk menemukenali persepsi ruang pada salah satu karya Andra Matin, yakni I\&L House.
\end{abstract}

${ }^{1}$ Corresponding Author: rafiiputraa@gmail.com 
Metode penelitian yang digunakan dalam penelitian ini merupakan deskriptif-kualitatif melalui pendekatan cinematic architecture. Data-data yang diambil sebagai bagan analisa adalah data elemen mental space, material space, dan lived space yang didapat melalui tiga instrumen pengumpulan yaitu observasi, wawancara, serta kuesioner. Teknik analisa yang dilakukan adalah gabungan dari analisa kuantitatif dan anaisa kualitatif dengan membandingkan hasil analisa pengamat dan hasil yang didapat dari pengambilan data persepsi melalui responden.

Kesimpulan yang didapat dari penelitian ini adalah seperti apa mental space dan material space pada objek. Kemudian elemen mental space dan material space yang paling signifikan memberikan pengaruh pada persepsi ruang yang terbentuk seperti masculine, directing, peaceful, serta exposed dalam elemen lived space penggguna I\&L House seperti material, bentuk, cahaya, dan suara. Pada akhir penelitian, penulis menggunakan film sebagai sarana untuk memvisualisasikan kesimpulan yang didapat.

Kata-kata kunci : cinematic architecture, Andra Matin, i\&l house.

\section{PENDAHULUAN}

Hubungan antara film dan arsitektur telah tersirat setidaknya sejak film Le Corebusier, L'archutecture d'Audjourd'hui. Pada tahun 1927 (mengingat bahwa film tersebut ditemukan sekitar tahun 1895 oleh Lumiere bersaudara), mungkin layak untuk mengemukakan bahwa titik dasar persimpangan antara kedua bidang ini adalah gagasan meta-representasional tentang media (Pallasmaa, 2001). Meta-representasional yang dimaksud adalah kemampuan untuk menghasilkan pengetahuan atau makna baru melalui representasi pemikiran atau konsep yang tidak diperhatikan sehari-hari. Kemampuan untuk mewakili representasi pemikiran dan konsep dari refleksi dan pemikiran tinggi mengenai sebuah media penyampaian (Norman, 1993). Sepanjang film dapat dipahami dan diinterpretasikan sebagai sarana dan ruminasi terhadap rasa, persepsi, dan emosi yang sangat besar, sehingga dapat dieksplorasi juga berkaitan dengan arsitektur yang juga terkait dengan proyeksi rasa, persepsi, dan emosi. Jadi, gagasan arsitektur yang terkait dengan persepsi mungkin terkait erat dengan gagasan film (Pallasmaa, 2001).

Mengutip dari artikel sebuah tulisan oleh David Hutama seorang kurator dan dari media arsitektur rooang.com, mengatakan ruang yang terbentuk dari desain Andra Matin memberikan kesan terhubung antara satu tingkat dengan tingkat lain memiliki sifat sinematik karena desain Andra Matin yang memiliki respon estetis secara emosional melalui sekuensi pengalaman pengamat atau pengguna (User Oriented Design), serta garis minimalis dengan struktur geometris adalah gaya khas dari Andra Matin.

I\&L House merupakan salah satu karya residensial yang unik dari Andra Matin karena dibangun di tengah eksisting pepohonan palm. Hal ini menjadi hal yang menarik karena sikap terhadap eksisting memberikan konsekuensi desain sehingga tercipta gubahan-gubahan yang berupa struktural maupun ragam elemen yang mencitrakan dan menceritakan pesan yang ingin disampaikan dari perancang dan pengguna melalui bentuk, keterhubungan ruang, dan sequential yang ada.

Menjadi lebih menarik untuk menelaah lebih dalam mengenai I\&L House dari sudut padang Cinematic Architecture dan bagaimana respon secara emosional melalui sekuensi pengalaman ruang yang dialami penguna menjadi ciri khas dari arahan desain Andra Matin. Dari banyak bahasan mengenai arsitektur sinema, skripsi ini mengambil pendekatan sequential yang akan menelaah tentang ruang mental, ruang fisik dan ruang yang dihidupi di I\&L House.

Secara geografis, I\&L House terletak di kelurahan Pondok Pucung kecamatan Pondok Aren, Kota Tangerang Selatan, Banten. Lokasi I\&L House berbatasan langsung dengan daerah Perumahan Bintaro Sektor 9 dan berjarak sekitar 20 kilometer dari Jakarta Selatan. 


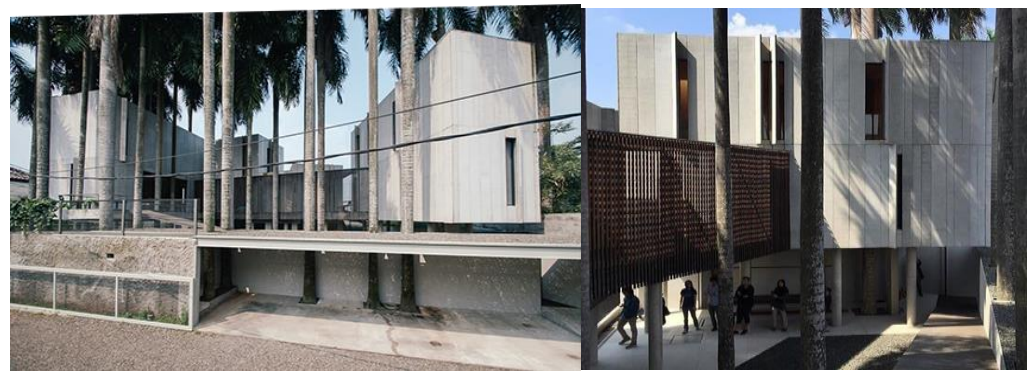

Gambar 1.2. I\&L House

(Sumber: Instagram.com/andramatin)

\section{KAJIAN TEORI}

\subsection{SINEMA DALAM ARSITEKUR}

Cinema Architectural adalah istilah yang mencakup berbagai taktik naratif spasial yang menjelaskan konfigurasi baru sinema spasial di mana narasi tertanam di dalam ruang. Sinematik arsitektur tidak memiliki nilai utilitarian atau inheren-karakter, arsitektur berinteraksi dan saling menunjuk satu sama lain. Suasana episode sinematik diberikan oleh arsitektur makna dan cara diproyeksikan di tempat.

\subsubsection{SINEMA SEBAGAI ARSITEKTUR}

Semua film memiliki lapisan arsitektural di dalamnya, apakah bangunan sebenarnya seperti yang ditunjukkan dalam film atau tidak, karena tindakan penggarapan gambar, definisi skala atau iluminasi, menyiratkan pembentukan tempat yang berbeda. Di sisi lain, pendefinisian tempat adalah tugas pokok dari arsitektur. Para arsitek berusaha menciptakan potensial ruang yang membawa rasa tempat di benak pengguna.

\subsubsection{ARSITEKTUR SEBAGAI ALAT SINEMATIK}

Beberapa masalah klasik dari studi perilaku lingkungan, ruang pribadi, territoriality, crowding; persepsi lingkungan, kognisi, dan simbolisme telah memainkan peran dramatis di dalam sinema/film. Arsitektur dan lingkungan binaan telah digunakan sebagai kendaraan untuk berbagai perangkat sinematik (Diane, 1996).

- Arsitektur sebagai latar belakang atau set tempat.

- Pengguna arsitektur untuk meningkatkan mood dan konteks

- Perwujudan metafora melalui arsitektur

- Representasi langsung elemen narasi melalui arsitektur

- Arsitektur sebagai karakter aktif

\subsection{ARCHITETCURAL SPACE AND FILM SPACE}

Poetics of Architecture membahas pembuatan arsitektur dan film secara bersamaan sebagai "tindakan konstruksi fisik dan tindakan mental untuk menafsirkan" Sementara hubungan antara ruang arsitektural dan ruang film kita harus ingat bahwa ruang pada akhirnya dihasilkan di dalam pikiran kita. Ruang filmik adalah ruang rekonfigurasi dari visualisasi yang kita terima di layar. Inilah yang membantu kita mengasimilasi narasi dan orientasi di layar. Film (sinema) membangun 
ruang di ruang pikiran-pikiran yang mencerminkan arsitektur secara singkat dalam pikiran manusia dan emosi. Ini adalah penggabungan dari persepsi dan pengalaman ruang (ruang fisik) dengan pengetahuan kita yang melekat (knowledge), aklamasi kontekstual (place), kenangan masa lalu (history) dan jiwa (ruang pikiran). Perpaduan antara 'ruang pikiran' dan 'ruang fisik' merupakan 'ruang hidup' (Pallasmaa, 2001).

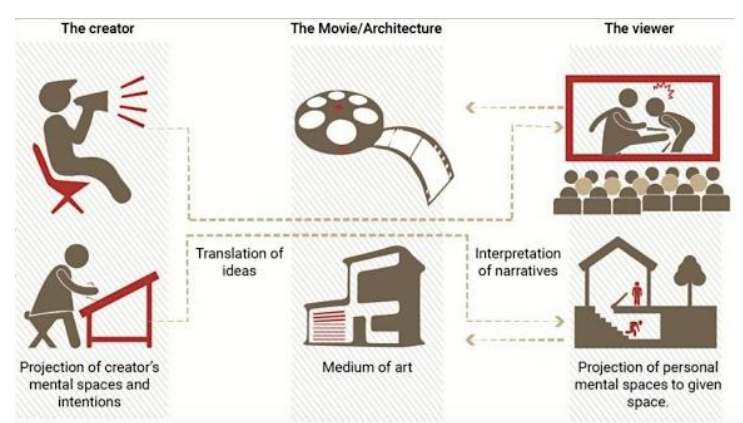

Gambar 2.1 Proses mental dibalik mengonsep dan persepsi dari bangunan

(Sumber: Preetika B, 2015)

Ruang mental adalah gagasan bawah sadar ruang yang independen terhadap realitas fisik ruang dan waktu. Lived space atau ruang penerimaan adalah kombinasi antara ruang luar dan ruang batin, di mana memori dan mimpi, ketakutan dan keinginan, value dan meaning, bercampur dengan persepsi yang sebenarnya. Bentuk pengalaman arsitektur dan sinema menjadi identik dalam ruang mental ini, yang berkelok-kelok tanpa batas-batas tertentu.

Bahkan seni arsitektur, citra mental dipindahkan dari ranah pengalaman arsitek ke dunia mental pengamat, dan material bangunan adalah benda mediasi objek gambar.

$$
\begin{gathered}
\text { Mental Space } \\
\text { (Imagined space) } \\
\text { (real space) }
\end{gathered}
$$

Pembuat film selalu mengakui bahwa yang ditemui, diingat, dan dibayangkan adalah pengalaman yang sama dalam kesadaran kita. Kita mungkin sama-sama tergerak oleh sesuatu yang ditimbulkan oleh imajinasi seperti yang sebenarnya ditemukan. Peran pikiran dan ruang mental dalam membantu pemahaman ruang film sangat penting dalam menafsirkan narasi oleh penonton. Kita melihat batas-batas ruang film yang tak terlihat oleh isyarat yang kita terima-seperti gerak, suara, cahaya, dan jangkauan bingkai (framing). Ruang filmik menyoroti aspek spesifik ruang fisik seperti ruang sosial, ruang sensor, dan lain-lain, yang oleh arsitek berkontribusi mengapa inflix sinema dalam arsitektur adalah cara yang baik untuk memperluas pemahaman kita tentang ruang fisik dan mental.

Dalam bukunya, Juhani Pallasmaa mengatakan bahwa "Experiencing a space is a dialogue, a kind of exchange-I place my self in the space and the space settles in me. This identification of physical and mental space is intuitively grasped by writers and film directors (and not so by architects)." 
Kita membutuhkan pendekatan secara sinematik ke arsitektur dan pendekatan secara arsitektural ke sinema, serta pengetahuan tentang satu domain dapat memperkaya yang lain. Kemampuan film untuk mensimulasikan ruang mental adalah titik penting di mana arsitektur dan film bertemu. Film, dalam menghasilkan ruang, menjadi arsitektur.

\section{Mental Space}

Untuk mengtahui elemen mental space apa saja yang ada dan berhubungan dengan material space dan lived space, peneliti mengumpulkan dari 2 tokoh yakni Juhani Pallasmaa dari bidang sinema arsitektur dan Steven Holl dari bidang persepsi. Elemen-elemen tersebut kemudian diharapkan dapat melengkapi material space dalam mengungkap lived space dari pengguna bangunan. Berikut adalah tabel elemen berdasarkan tokoh. Pada elemen mental space dilakukan proses seleksi dan pengklasifikasian elemen, karena pada tabel di atas masih ada elemen yang menjadi bagian dari elemen lain. Hal ini dilakukan karena elemen di atas akan digunakan untuk mengetahui seperti apa dan apa saja mental space yang ada di I\&L House. Dari proses yang terlah dilakukan, didapatkan 4 elemen yakni Story, Concept, Knowledge, Idea.

\section{Material Space}

Penulis mengumpulkan elemen material ruang yang berhubungan dengan mental dan lived space dari dua tokoh yakni Juhani Pallasmaa dari bidang sinema arsitektur dan Steven Holl dari bidang persepsi. Elemen-elemen tersebut kemudian penulis urutkan berdasarkan keterukuran dan kemudian penulis seleksi dan klafisifikasikan. Dari data elemen yang sudah penulis seleksi dan klasifikasikan, didapat 9 elemen yang dianggap dapat mewakili beberapa elemen lain serta berpengaruh terhadap Lived Space pengguna bangunan I\&L House. Elemen-elemen tersebut adalah Tempat, Bentuk, Ukuran, Waktu, Cahaya, Suara, Material, dan Alur pada bangunan.

\section{Lived Space (Final Preceived Space)}

Dalam bukunya yang berjudul The Architecture of Image: Existential Space in Cinema, Juhani Pallasmaa menjelaskan bahwa Lived Space atau Final Preceived Space menyerupai struktur mimpi dan dibawah alam sadar yang merupakan hasil dari pengolahan informasi yang diterima indra sensory dan terorganisir secara independen terhadap batasan ruang fisik dan waktu (Pallasmaa, 2000). Lived space selalu merupakan kombinasi antara ruang luar dan ruang batin, aktualitas dan proyeksi mental. Lived space adalah ruang yang tak terpisahkan dengan situasi kehidupan konkurensi subjek. Kita tidak hidup terpisah di dunia material dan mental. Dimensi pengalaman ini sepenuhnya saling terkait. Kita juga tidak tinggal di dunia yang objektif. Kita hidup di dunia mental, di mana yang dialami, diingat dan dibayangkan, dan juga masa lalu, masa kini dan masa depan tidak bercampur aduk (Pallasmaa, 2001).

Dalam pembahasan mengenai komponen lived space, peneliti juga mengumpulkan elemen tersebut dari dua tokoh yakni Juhani Pallasmaa dari bidang sinema arsitektur dan Michael Hendrix dari bidang persepsi. Michaek Hendrix membagi klasifikasi persepsi yang beliau lakukan berdasarkan lima indra yang dimiliki manusia sebagai alat sensory, yaitu Pendengaran $\rightarrow$ Sound, Pengelihatan $\rightarrow$ Sight, Penciuman $\rightarrow$ Smell, Pengecap $\rightarrow$ Taste, dan Peraba $\rightarrow$ Touch. Sebagai penangkap informasi sebelum diterima oleh otak dan diolah menjadi persepsi pada sensory suara, Michael Hendrix menklasifikasikan dua klasifikasi yang berlawanan, Loud - Quiet. Pada penelitiam ini, penulis memasukan sensory suara karena suara juga menjadi elemen pada material space yang sudah dirumuskan sebelumnya. penulis hanya memilih dua komponen klasifikasi persepsi yang saling berlawanan, yakni Noticable - Peaceful. Di mana yang kita tahu, Noticable berhubungan dengan jenis suara dan kuat suara dan Peaceful pada sensory suara berhubungan deengan ada tidaknya suara, dan jenis suara. Melihat banyaknya komponen persepsi yang terdapat pada sensory sight, penulis hanya memilih 2 komponen klasifikasi persepsi yang saling 
berlawanan di setiap klasifikasi persepsi terpilih. Klasifikasi dan komponen terpilih adalah: Static - Moving (Peaceful x Energetic), Backward - Forward (Historical x Visionary) (Contemplative $\mathrm{x}$ Progressif), Tight - Loose (Formal x Casual) (Limited x Open), Murky - Clear (Confused x Exposed), Dark - Bright (Melancholy x Cheerful).

Persepsi yang termasuk kedalam sensory touch namun setelah penulis telaah lebih dalam serta berdasarkan pengalaman penulis ketika melakukan observasi pada kunjungan pertama, penulis hanya memilih empat klasifikasi serta komponen persepsi yang relevan terbentuk di I\&L House. Adapun kelasifikasi dan kompenen persepsi yang terpilih adalah Smooth - Rough (Feminine x Masculine), Heavy - Light (Serious x Fun), Warm - Cold (Comforting x Lonely), Dull-Sharp (Boring x Directing).

\section{METODA PENELITIAN}

Pendekatan dan jenis penelitian yang dilakukan merupakan penelitian Campuran Kualitatif-Kuantitatif dengan pembahasan secara deskfiptif di mana yang dimaksud dengan memaparkan analisa objek berdasarkan pendekatan Cinematic Architecture pada bangunan yang bersifat kualitatif didapatkan dari hasil observasi peneliti dan observasi terhadap responden.

\subsection{ANALISIS KONTEN (KUALITATIF)}

Analisis konten (kualitatif) merupakan analisis data kualitatif di mana peneliti mencoba untuk memahami setiap jawaban (berupa teks) dari responden. Hasil rekap dari instrumen tersebut kemudian diidentifikasi dengan karakteristik elemen Mental Space, Material Space, dan Lived Space yang merupaan hasil elaborasi teori pada bab sebelumnya.

\subsection{ANALISIS DISTRIBUSI (KUANTITATIF)}

Analisis distribusi (kuantitatif) digunakan penulis untuk melihat kecenderungan jawaban respoden dari frekuensi jawaban yang paling sering muncul pada tahap rekapitulasi. Mengingat rekap pada kuesioner dilakukan terpisah antara Material Space dan Lived Space, sehingga hasil dari setiap rekap tersebut harus dipertemukan kembali dengan mengidentifikasi hasil rekapitulasi Lived Space apa yang paling terpengaruh oleh kehadiran Material Space demi mendapatkan kesimpulan yang valid dan objektif.

Data dalam penelitian ini dibagi menjadi 3 berdasarkan kebutuhan yang muncul dari teori yang digunakan yakni:

1. Data fisik (Material Space): Tempat, Bentuk, Ukuran, Suara, Material, Cahaya, Waktu, Alur.

2. Data mental (Mental Space): Konsep, Cerita, Ide.

3. Data persepsi (Lived Space): Klasifikasi persepi.

Untuk mempersingkat proses pengumpulan data tersebut penulis menyajikannya dalam bentuk tabel.

Tabel 3.1. Tabel Instrumen Data

\begin{tabular}{|c|l|l|l|l|}
\hline \multicolumn{1}{|c|}{ Unit Data } & \multicolumn{1}{|c|}{ Data } & Sumber Data & \multicolumn{1}{c|}{$\begin{array}{c}\text { Instrumen } \\
\text { Pengumpulan Data }\end{array}$} & \multicolumn{1}{c|}{ Teknis } \\
\hline Material Space & $\begin{array}{l}\text { Tempat, Bentuk, } \\
\text { Ukuran, Suara, }\end{array}$ & $\begin{array}{l}\text { Observasi } \\
\text { Lapangan }\end{array}$ & $\begin{array}{l}\text { Dokumentasi foto, } \\
\text { pengambilan gambar }\end{array}$ & $\begin{array}{l}\text { Persiapan: } \\
\text { Kamera, alat tulis }\end{array}$ \\
\hline
\end{tabular}




\begin{tabular}{|c|c|c|c|c|}
\hline & $\begin{array}{l}\text { Material, Cahaya, } \\
\text { Waktu, dan Alur pada } \\
\text { bangunan. }\end{array}$ & & (video). & $\begin{array}{l}\text { Pelaksanaan: } \\
\text { pemotretan, } \\
\text { Perekaman data } \\
\text { Olah data: } \\
\text { Digitalisasi } \\
\end{array}$ \\
\hline Mental Space & $\begin{array}{l}\text { Cerita / Latar } \\
\text { Belakang, , konsep, } \\
\text { dan ide dari I\&L } \\
\text { House. }\end{array}$ & $\begin{array}{l}\text { Pak Hendrikus } \\
\text { (owner) }\end{array}$ & $\begin{array}{l}\text { Wawancara, List } \\
\text { pertanyaan. }\end{array}$ & $\begin{array}{l}\text { Persiapan: } \\
\text { Pertanyaan, alat } \\
\text { tulis, kertas, } \\
\text { kuesioner } \\
\text { Pelaksanaan: } \\
\text { Wawancara, } \\
\text { pencatatan jawaban. } \\
\text { isepiolah data: } \\
\text { Lembar wawancara } \\
\text { dan digitalisasi. }\end{array}$ \\
\hline $\begin{array}{l}\text { Lived Space (Final } \\
\text { Precived Sapce) }\end{array}$ & $\begin{array}{l}\text { Pengaruh Mental } \\
\text { Space dan Material } \\
\text { Space } \\
\text { Terhadap Lived Space } \\
\text { penghuni I\&L House. }\end{array}$ & Penghuni & $\begin{array}{l}\text { Kuesioner dan } \\
\text { Wawancara, }\end{array}$ & $\begin{array}{l}\text { Persiapan: } \\
\text { Lembar kuesioner, } \\
\text { alat tulis. } \\
\text { Pelaksanaan: } \\
\text { Wawancara, } \\
\text { pencatatan } \\
\text { jawabanisep. } \\
\text { Olah Data: } \\
\text { Merekap Lembar } \\
\text { wawancara. }\end{array}$ \\
\hline
\end{tabular}

Data-data yang akan diteliti didapat melalui 3 macam instrumen pengumpulan data yakni, observasi, wawancara, dan kuesioner. Peneltiti melakukan rekapitulasi data dan mengolah data agar mempermudah dalam proses menganalisa serta penarikan kesimpulan. Rekapitulasi data dilakukan berbeda pada setiap instrument pengumpulan data. Adapun cara rekapitulasi tersebut adalah sebagai berikut.

1. Observasi

Instrumen data dengan observasi dilakukan untuk mengumpulkan data Material Space yaitu mengenai data fisik pada objek meliputi sekitar tapak dan bangunan yang dapat memengaruhi terbentuknya Lived Space pada pengguna. Rekapitulasi pada instrument pengumpulan data observasi dilakukan dengan penggambaran ulang objek dalam bentuk 3D yang kemudian digunakan sebagai sarana penyajian data fisik seperti material, kondisi eksisiting tapak, alur/sequence, dan layout bangunan dan lainnya.

\section{Wawancara}

Wawancara dilakukan untuk mengungkap serta mengumpulkan data Mental Space yang didapat dari bertanya dan mendengarkan cerita pemilik mengenai I\&L House. Kemudian data tersebut dituliskan kembali untuk mengetahui alur cerita dan dapat dianalisa nantinya. Data dari wawancara juga dirangkum yang kemudian rangkuman tersebut peneliti visualisasikan dengan mengunakan Film.

\section{Kuesioner}

Kuseionser merupakan instumen pengumpulan data paling akhir yang digunakan. Penggunaan kuseioner yang tersusun dari pertemuan antara elemen Material Space dengan elemen Lived Space di mana pada elemen Lived Space menggunakan skala diferensial diharapkan dapat membantu pengungkapan persepsi pengguna bangunan I\&L House. Adapun peneliti merekap jawaban responden dengan penjumlahan untuk mengetahui kecenderungan jawaban respondendari 
frekuensi jawaban dengan nilai paling besar untuk rekapitulasi Material Space dan nilai terbesar dan paling negative untuk rekapitulasi elemen Lived Space.

\section{ANALISA \\ 4.1 MENTAL SPACE}

Hasil identifikasi data wawancara;

Dari identifikasi yang dilakukan terhadap data wawancara kepada Pak Hendrikus sebagai pemilik rumah, penulis dapat melihat pola Mental Space yang terjadi atau terbetuk pada I\&L House. Pola tersebut tidak seperti runutan yang telah dirumuskan pada bab teori yakni Concept memunculkan Idea, tetapi runutan yang ada pada I\&L House adalah Idea memunculkan Concept. Hal tersebut dapat dilihat pada awal dan akhir wawancara, namun pada bagian akhir, Pak Hendrikus memaparkan bahwa hal tersebut bukan sebagai konsep awal, melainkan terjadi kecocokan antara bentukan rumah I\&L House dengan rumah tradisional di Kalimantan. Walaupun tidak disengaja, konsep awal mengenai zonasi dan program ruang kurang lebih sama.

\begin{tabular}{lll} 
Umum & $=$ Concept & \multicolumn{1}{c}{$\stackrel{\text { ded }}{\longrightarrow}$ Concent } \\
I\&I HoIIse $=$ Idea
\end{tabular}

Kemudian, penulis juga dapat melihat bahwa setiap elemen Mental Space dapat terjadi tumpang tindih atau overlap antara Story, Concept, dan Idea. Setelah ditelaah lebih dalam mengenai dua hal di atas, penulis menganggap bahwa runutan pemunculan elemen Mental Space dapat tidak sesuai dengan pemunculan elemen Mental Space pada umumnya dapat disebabkan oleh kemungkinan terjadinya overlaping konten pada elemen Mental Space, seperti yang terjadi pada I\&L House.

Selain menemukan seperti apa Elemen Space yang ada pada I\&L House, penulis juga mengidentifikasi data untuk menemukan potongan cerita yang dianggap memiliki informasi serta alur cerita untuk dapat digunkan sebagai acuan pembuatan naskah film pada bab kesimpulan. Penulis memberikan tanda nomor berdasarkan urutan yang dirasa cocok dan dapat menjelaskan maksud dari narasi owner secara singkat dan jelas.

\subsection{MATERIAL SPACE PADA I\&L HOUSE}

Analisa yang dilakukan pada Material Space adalah analisa distributif (kuantitatif) dan analisa konten (kualitatif). Analisa distribusi data kuesioner pada bagian Material Space dilakukan dengan menjumlah setiap elemen Material Space yakni Tempat, Bentuk, Ukuran, Suara, Material, Waktu, Cahaya, dan Alur di setiap ruangan berdasarkan jawaban 5 responden. Dari analisa tersebut dapat diketahui elemen Material Space apa saja yang paling berpengaruh di setiap ruangan secara khusus dan Material Space di I\&L House secara umum.

Pada analisa Material Space, objek juga dibahas berdasarkan elemen Material Space di atas. Namun ada beberapa material yang dibahas secara umum karena keberadaanya masih dapat dirasakan di setiap ruangan yang menjadi objek analisa fisik spasial ini, berikut adalah klasifikasinya.

Elemen Material Space Umum: 1. Tempat 2. Suara 3. Waktu 
Elemen Material Space Khusus: 1. Waktu 2. Bentuk 3. Ukuran 4. Material 5. Cahaya 6. Alur

Elemen waktu terdapat di kedua sifat di atas dikarenakan waktu pada sifat khusus berkaitan dengan durasi persepsi setiap pengguna terhadap I\&L House.

\subsection{MATERIAL SPACE DAN LIVED SPACE}

Analisa distribusi data kuesioner pada bagian Material Space dilakukan dengan menjumlah setiap elemen Material Space yakni Tempat, Bentuk, Ukuran, Suara, Material, Waktu, Cahaya, dan Alur di setiap ruangan berdasarkan jawaban lima responden. Dari analisa tersebut dapat diketahui elemen Material Space apa saja yang paling berpengaruh di setiap ruangan secara khusus dan Material Space di I\&L House secara umum.

Dibawah ini adalah hasil analisa distribusi yang sudah dilakukan pada kuesioner untuk elemen Material Space.

Tabel 3.1. Analisa Distribusi Material Space

\begin{tabular}{|c|c|c|c|c|c|c|c|c|c|c|}
\hline \multirow{2}{*}{$\begin{array}{l}N \\
0\end{array}$} & \multirow{2}{*}{ Responden } & \multirow{2}{*}{ Ruangan } & \multicolumn{8}{|c|}{ Ruang Material (Material Space) } \\
\hline & & & Tempat & Bentuk & Ukuran & Suara & Material & Waktu & Cahaya & Alur \\
\hline \multirow{6}{*}{1} & Ibu Linda & \multirow{5}{*}{ Lt. Dasar } & 1 & 2 & 2 & 2 & 3 & 1 & 3 & 1 \\
\hline & Pak Hendrikus & & 2 & 4 & 1 & 2 & 4 & 2 & 3 & 1 \\
\hline & Dita (PRT) & & 3 & 3 & 2 & 2 & 5 & 3 & 3 & 1 \\
\hline & Gita (karyawan) & & 3 & 3 & 1 & 2 & 2 & 3 & 3 & 2 \\
\hline & Mba Yuli (PRT) & & 2 & 1 & 5 & 3 & 5 & 1 & 2 & 1 \\
\hline & \multicolumn{2}{|c|}{ Jumlah } & 11 & 13 & 11 & 11 & 19 & 10 & 14 & 6 \\
\hline \multirow{6}{*}{2} & Mba Yuli (PRT) & & - & 4 & 1 & 2 & 5 & 1 & 1 & 2 \\
\hline & Gita (karyawan) & & 1 & 3 & 1 & 2 & 5 & 1 & 3 & 1 \\
\hline & Dita (PRT) & Dining & 1 & 1 & 1 & 2 & 2 & 1 & 2 & 1 \\
\hline & Pak Hendrikus & & - & 3 & 1 & 1 & 5 & 1 & 3 & 1 \\
\hline & Ibu Linda & & 1 & 1 & 1 & 2 & 4 & 1 & 4 & 1 \\
\hline & \multicolumn{2}{|c|}{ Jumlah } & 3 & 14 & 5 & 9 & 21 & 5 & 11 & 6 \\
\hline \multirow{6}{*}{3} & Ibu Linda & & 1 & 2 & 1 & 2 & 4 & 2 & 3 & 2 \\
\hline & Pak Hendrikus & & 1 & 3 & 2 & 2 & 5 & 2 & 4 & 4 \\
\hline & Dita (PRT) & Sirkulasi & 1 & 2 & 2 & 2 & 3 & 2 & 2 & 1 \\
\hline & Gita (karyawan) & & 1 & 3 & 1 & 2 & 5 & 3 & 2 & 1 \\
\hline & Mba Yuli (PRT) & & - & 4 & 3 & 2 & 5 & 2 & 4 & 1 \\
\hline & \multicolumn{2}{|c|}{ Jumlah } & 4 & 14 & 9 & 10 & 22 & 12 & 15 & 9 \\
\hline \multirow{6}{*}{4} & Mba Yuli (PRT) & & 1 & 5 & 2 & 1 & 4 & 4 & 2 & 1 \\
\hline & Gita (karyawan) & & 1 & 2 & 2 & 2 & 5 & 2 & 3 & 1 \\
\hline & Dita (PRT) & Kantor & 1 & 2 & 1 & 2 & 4 & - & 1 & 1 \\
\hline & Pak Hendrikus & & 1 & 1 & 3 & 2 & 4 & 3 & 2 & 1 \\
\hline & Ibu Linda & & 1 & 1 & 2 & 1 & 2 & 1 & 2 & 2 \\
\hline & \multicolumn{2}{|c|}{ Jumlah } & 5 & 11 & 9 & 8 & 19 & 10 & 10 & 6 \\
\hline \multirow{6}{*}{5} & Ibu Linda & & - & 3 & 2 & 1 & 4 & 1 & 3 & - \\
\hline & Pak Hendrikus & & - & 4 & 2 & 2 & 4 & 2 & 3 & 2 \\
\hline & Dita (PRT) & $\begin{array}{l}\text { Perpusta- } \\
\text { kaan }\end{array}$ & - & 3 & 1 & 1 & 3 & 1 & 1 & 1 \\
\hline & Gita (karyawan) & & - & 3 & 1 & 2 & 3 & 1 & 2 & 1 \\
\hline & Mba Yuli (PRT) & & 1 & 4 & 1 & 2 & 3 & 2 & 2 & 2 \\
\hline & \multicolumn{2}{|c|}{ Jumlah } & 1 & 17 & 7 & 8 & 17 & 8 & 11 & 6 \\
\hline \multicolumn{3}{|c|}{ TOTAL } & 19 & 69 & 41 & 46 & 98 & 45 & 61 & 33 \\
\hline \multicolumn{3}{|c|}{ Peringkat } & 8 & 2 & 6 & 4 & 1 & 5 & 3 & 7 \\
\hline
\end{tabular}

Dari tabel di atas penulis dapat mengetahui elemen apa saja yang paling memengaruhi terbentuknya persepsi pada setiap ruangan melalui kesan yang ditimbulkan dari adanya elemen tersebut. Namun overlaping disetiap elemen Material Space terhadap persepsi apa saja yang dipengaruhi sangat mungkin terjadi. Oleh karena itu penulis kembali menjabarkan tabel di atas berdasarkan konten persepsi di setiap ruangannya. Kemudian penulis juga melakukan analisa distributif. 
Untuk dapat mengemukakan elemen persepsi dalam Lived Space pengguna terhadap I\&L House, penulis menggunakan metode skala diferensial yang di perkenalkan oleh Charles Osgood (1967). Metode tersebut memberikan 2 pilihan pernyataan yang memiliki sifat berlawanan. Di antara kedua pernyataan tersebut terdapat lingkaran berjumlah ganjil, dan setiap lingkaran mewakili 1 nilai sebagai parameter kecenderungan pada pernyataan yang dipilih.

Kemudian dari data dari kuerioner mengenai persepsi terbentuk, analisa dilakukan dengan menggunakan analisa distribusi (kuantitatif) yakni dengan menjumlahkan poin dari responden per persepsi untuk dapat melihat kecenderungan jawaban responden terhadap persepsi yang dirasa untuk satu tempat di I\&L House ya. Di mana kuesioner disediakan 1 rangkaian kuesioner untuk 1 ruang yang telah disusun secara sequential. Kemudian dilanjutkan dengan analisa konten (kualitatif). Hal ini juga dilakukan agar didapat hasil analisa yang objektif dan valid. Mengingat terdapat komponen persepsi yang terdapat di dua elemen klasifikasi Lived Space yang dikeluarkan oleh Michael demi meminimalisir overlap data yang ada.

Sebelum masuk pada rekapitulasi data, ada beberapa keterangan yang dibuat sebagai kesepakatan untuk mempersingkat dan memperjelas penyajian diagram rekapitulasi data. Keterangan tersebut adalah:

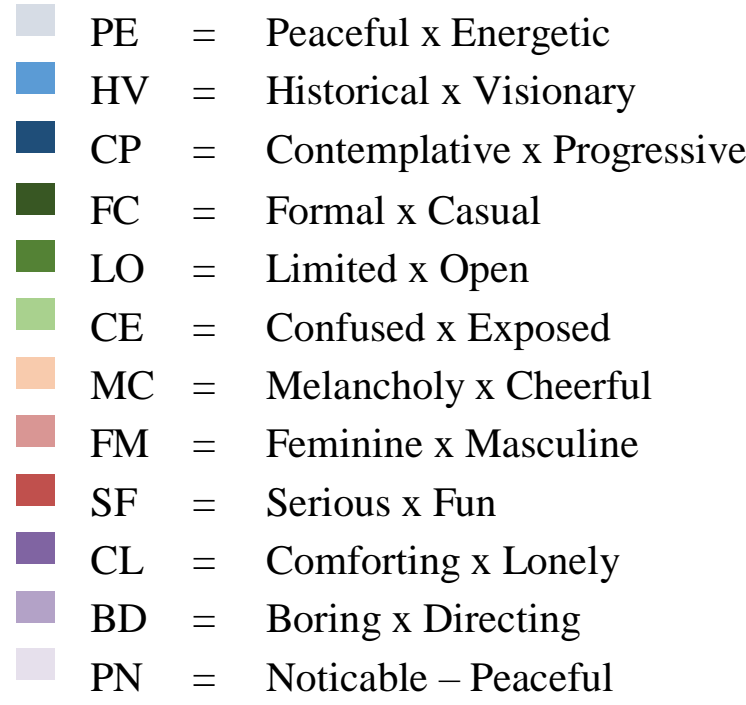

Tabel 3.2. Analisa Distribusi Lived Space 


\begin{tabular}{|c|c|c|c|c|c|c|c|c|c|c|c|c|c|c|}
\hline \multirow{2}{*}{$\begin{array}{l}N \\
0\end{array}$} & \multirow{2}{*}{ Responden } & \multirow{2}{*}{ Ruangan } & \multicolumn{12}{|c|}{ Elemen Klasifikasi Persepsi (Lived Space) } \\
\hline & & & PE & HV & CP & FC & LO & CE & MC & FM & SF & CL & BD & PN \\
\hline \multirow{6}{*}{1} & Ibu Linda & & 2 & 0 & 0 & 3 & 3 & -2 & 3 & 2 & 0 & 0 & -3 & -3 \\
\hline & Pak Hendrikus & & 0 & 1 & -3 & 3 & 3 & 2 & 3 & 3 & -2 & -2 & 0 & -2 \\
\hline & Dita (PRT) & Lt. Dasar & -2 & 1 & 1 & 3 & 2 & 2 & 1 & 2 & 2 & 2 & -1 & -3 \\
\hline & Gita (karyawan) & & -3 & -2 & -2 & 2 & 2 & -1 & -1 & 1 & 1 & 1 & 2 & 2 \\
\hline & Mba Yuli (PRT) & & -1 & 3 & 1 & 2 & 2 & 1 & 1 & 3 & 2 & 2 & 2 & -3 \\
\hline & \multicolumn{2}{|c|}{ Jumlah } & -4 & 3 & -2 & 14 & 12 & 2 & 7 & 11 & 3 & -11 & 0 & -3 \\
\hline \multirow{6}{*}{2} & Mba Yuli (PRT) & & 1 & 2 & 2 & 1 & -1 & 2 & 2 & 0 & 2 & -2 & 2 & -2 \\
\hline & Gita (karyawan) & & -1 & 0 & 0 & -1 & -1 & 2 & -2 & 2 & -1 & -2 & 3 & -2 \\
\hline & Dita (PRT) & Dining & -2 & 1 & -1 & 3 & 1 & 2 & 3 & 3 & 1 & 0 & 3 & -3 \\
\hline & Pak Hendrikus & & -2 & 1 & -1 & 2 & 1 & 2 & 2 & 1 & 2 & -2 & 3 & -2 \\
\hline & Ibu Linda & & -2 & 0 & 0 & 1 & 0 & 2 & 2 & 0 & 0 & -2 & 0 & -2 \\
\hline & \multicolumn{2}{|c|}{ Jumlah } & -6 & 4 & 0 & 6 & 0 & 10 & 7 & 6 & 3 & -8 & 11 & -13 \\
\hline \multirow{6}{*}{3} & Ibu Linda & & -2 & 0 & -1 & -2 & -2 & 2 & -1 & -2 & 0 & -2 & 3 & -2 \\
\hline & Pak Hendrikus & & 1 & 1 & 1 & 2 & 2 & 2 & 0 & 2 & -2 & -1 & 3 & -2 \\
\hline & Dita (PRT) & Sirkulasi & -2 & 0 & 0 & 2 & 2 & 1 & 2 & 2 & -3 & -2 & 3 & -2 \\
\hline & Gita (karyawan) & Kamar & -2 & 0 & -2 & -2 & -1 & 2 & -2 & 2 & 2 & 2 & 3 & -3 \\
\hline & Mba Yuli (PRT) & & -2 & 0 & 0 & -2 & -1 & 2 & -2 & 2 & -2 & 1 & 3 & -3 \\
\hline & \multicolumn{2}{|c|}{ Jumlah } & -9 & 1 & -2 & -2 & 0 & 9 & -3 & 6 & -5 & -2 & 15 & -9 \\
\hline \multirow{6}{*}{4} & Mba Yuli (PRT) & & 2 & 2 & 3 & -3 & -2 & 2 & 2 & 2 & -1 & -1 & 2 & -3 \\
\hline & Gita (karyawan) & & -2 & 0 & -2 & -2 & -1 & 2 & 3 & 2 & 1 & -1 & 3 & -2 \\
\hline & Dita (PRT) & Kantor & 2 & 1 & 1 & -2 & -2 & 2 & -2 & 2 & -3 & 2 & 3 & -1 \\
\hline & Pak Hendrikus & & 2 & 2 & 2 & -2 & -2 & 2 & 2 & 2 & -1 & 2 & 2 & -2 \\
\hline & Ibu Linda & & 1 & 0 & 0 & -2 & -2 & 0 & 1 & -1 & 2 & -1 & 3 & -2 \\
\hline & \multicolumn{2}{|c|}{ Jumlah } & 5 & 5 & 4 & -11 & -9 & 8 & 6 & 7 & -1 & -1 & 13 & -10 \\
\hline \multirow{6}{*}{5} & Ibu Linda & & 0 & 0 & 0 & -2 & & 1 & 1 & 2 & -2 & 2 & -3 & -2 \\
\hline & Pak Hendrikus & & 2 & 3 & 2 & 2 & 2 & 2 & 3 & 2 & 2 & -1 & 2 & -2 \\
\hline & Dita (PRT) & Petpusta- & 0 & 2 & -1 & -1 & 3 & 2 & -2 & 2 & 3 & -2 & 2 & -3 \\
\hline & Gita (karyawan) & & -2 & 2 & 0 & 2 & 2 & 3 & 2 & 2 & -1 & -2 & 3 & -2 \\
\hline & Mba Yuli (PRT) & & -2 & 0 & -1 & -3 & 2 & 2 & 3 & 3 & -3 & 0 & 2 & -3 \\
\hline & \multicolumn{2}{|c|}{ Jumlah } & -2 & 7 & 0 & -2 & 7 & 10 & 7 & 11 & -1 & -3 & 6 & -12 \\
\hline \multicolumn{3}{|c|}{ TOTAL } & -16 & 20 & 0 & 5 & 10 & 39 & 24 & 41 & -1 & -24 & 45 & -47 \\
\hline \multicolumn{3}{|c|}{ Peringkat } & 10 & 7 & 12 & 9 & 8 & 4 & 5 & 3 & 11 & 6 & 2 & 1) \\
\hline
\end{tabular}

Di atas adalah proses analisa distributif di mana pengakumulasian data kuesioner untuk mengetahui kecenderungan persepsi pengguna di setiap ruangan yang dijadikan objek penelitian.

\subsection{LT. DASAR}

Alur atau sequence yang terbentuk dari gubahan I\&L House tidak konvensional sepeti rumah pada umumnya yang memiliki program ruang yang sama. Pada bangunan I\&L House runut ruang menjadi sedikit berbeda tetapi tetap berdasarkan penzoningan aktivitas yang di wadahi.

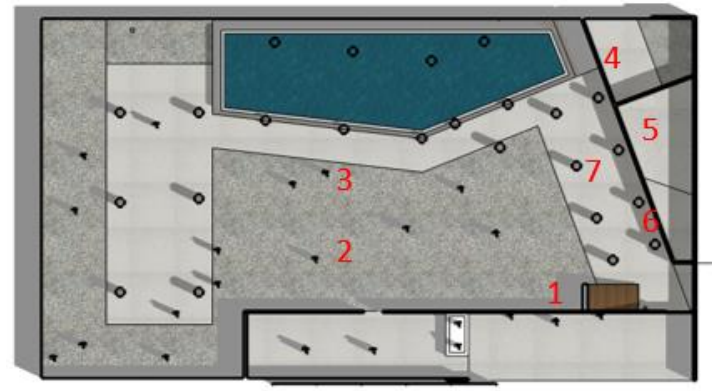

1. Garasi

2. Gudang\& Entrance

3. Open Plan

4. K. Mandi

5. Dapur

6. Ramp

7. Area Makan

Lt. Dasar pada objek memiliki bentuk layout open plan hanya ada ruangan-ruangan lain penunjang rumah serta area makan yang menjadi area digemari oleh keluarga Pak Hendrikus. Terdapat pula kolam renang pada sisi depan dari pintu masuk. Kolam renang juga menjadi salah satu elemen Material Space yang dominan selain material laim di Lantai Dasar I\&L House. 
Elemen Material Space yang dirasakan oleh ke 5 responden mempengaruhi Elemen Lived Space di Lt. Dasar

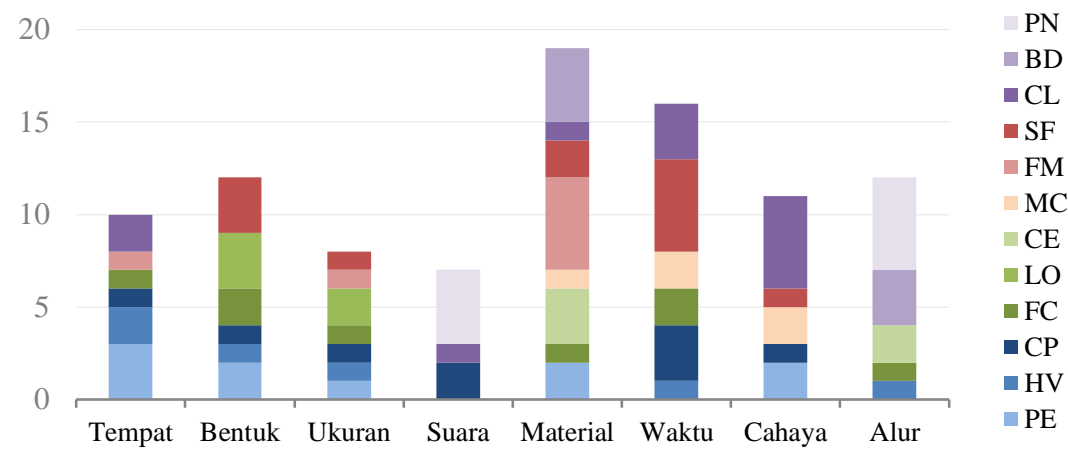

Berdasarkan hasil kuesioner, elemen Material memiliki kecenderungan sebagai elemen ruang fisik paling berpengaruh terhadap pembentukan persepsi Lived Space adalah jenis-jenis material pada Lt. Dasar. Disusul dengan Waktu-Bentuk-Alur-Cahaya-Tempat. Adapun kecenderungan material adalah mempengaruhi persepsi;

1. Peaceful-Energytic 2 dari 25 kali dipilih,

2. Formal-Casual 1 dari 25 kali dipilih

3. Confused-Exposed 3 dari 25 kali dipilih

4. Melancholy-Cheerful 1 dari 25 kali dipilih

5. Faminine-Masculine 6 dari 25 kali diplih

6. Serious-Fun 2 dari 25 kali dipilih

7. Comforting-Lonely 1 dari 25 kali dipilih

8. Bored-Directing 5 dari 25 kali dipilih

Terdapat 2 klasifikasi yang paling signifikan terpengaruh oleh keadaan material bangunan yang digunakan LT. Dasar, yakni:

Feminine-Masculine dan Boring-Directing

Persepsi yang dirasakan oleh ke 5 responden terhadap Elemen Material Space di LT. Dasar 


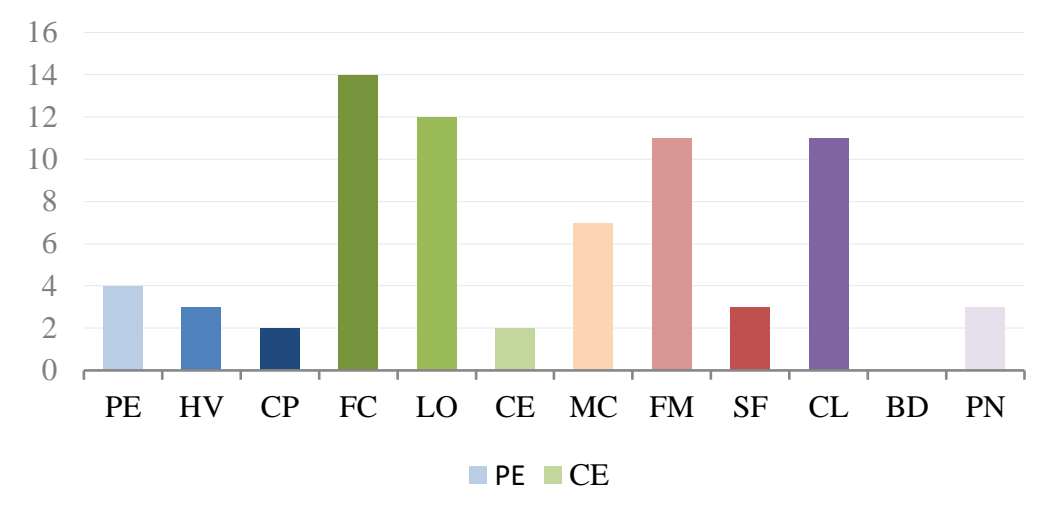

Dari gambar skala di atas kita dapat mengetahui bahwa persepsi yang paling banyak dirasakan oleh pengguna di Lantai Dasar adalah persepsi:

\section{Casual - Open-Masculine - Lonely}

Persepsi di atas berkaitan dengan keadaan fisik dan eksisting yang terdapat pada lantai dasar. Pak Hendrikus menceritakan kegiatan-kegiatan yang biasa dilakukan di daerah Lt. Dasar. Karena bentuknya yang open plan, Pak Hendrikus dan keluarga bisa melakukan kegiatan yang sebelumnya tidak bisa dilakukan di rumah terdahulunya, di apartement.

Semenjak pindah ke daerah Bintaro dan tinggal di I\&L House banyak pengalama baru dirasakan oleh Pak Hendrikus dan keluarga. Seperti beliau bisa memelihara binatang dan bermain dengan binatang peliharaan, mengadakan pesta kecil untuk orang terdekat, sampai ketika terjadi hujan di pun Pak Hendrikus dan keluarga membersihkan. Terdengar petir kencang, hujan lebat, semuanya menjadi irama tersendiri. Hal tersebut yang dimaksud dengan Casual oleh Pak Hendrikus dan Keluarga, kegiatan tidak kaku dan bebas.

\section{Dominasi Material Space dan Lived Space di Lt. Dasar}

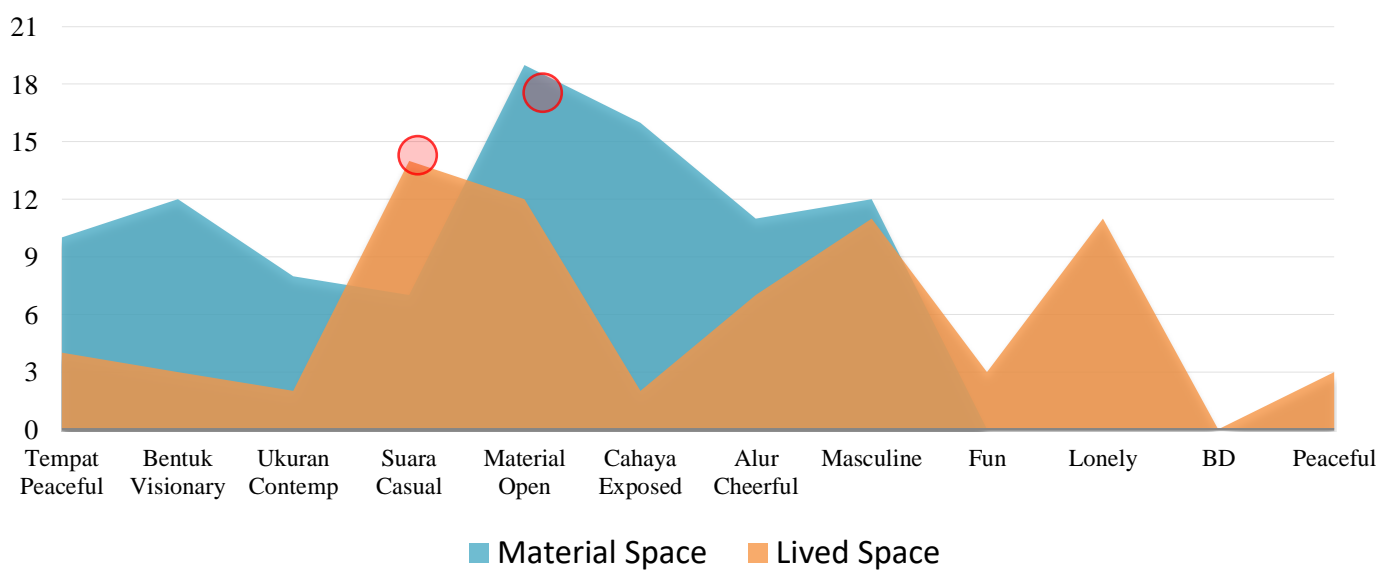


Di atas adalah dominasi dari kedua elemen yang menunjukan kecenderungan kedua elemen yang terjadi di Lt. Dasar. Yaitu Material dan Casual. Penggunaan matrix ditujukan untuk mempermudah rekapitulasi hasil analisa konten yang telah dilakukan berikutnya.

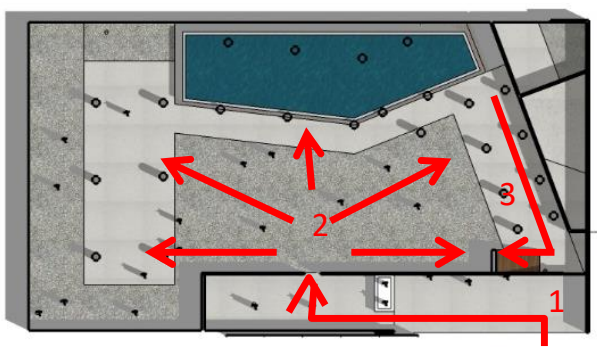

1. Continuity Montage

2. Inter-sequential Montage

3. Continuity Montage

Sekuensial yang terjadi pada Lt. Dasar terdiri dari dua tipe, yaitu Inter-sequential Montage dan Continuity Montage (Modii, 2015). Terjadinya perpaduan dua tipe ini dikarenakan pada Lt. Dasar terdapat tiga jenis ruang yang memiliki perbedaan karakter. Pertama area garasi sampai ke gudang dan pintu masuk terbentuk dari susunan dinding yang memberi raut bentuk persegi panjang, hal tersebut sangat mengarahkan sirkulasi menuju satu titik. Kedua adalah ruangan dengan karakter open plan. Ketika masuk penulis disodori sebuah area luas dengan material penutup kerikil tanpa bantuan garis yang mengarahkan baik dari penutup material atau bentukan fisik dari bangunan meliputi lantai, dinding, dan atap. Maka terjadi berbagai kemungkinan penentuan arah oleh pengunjung tanpa dipengaruhi elemen fisik spasial. Ketiga adalah area yang paling memanfaatkan elemen fisik spasial pelingkup ruang, dari material yang berbeda dengan area open plan, tata ruang serta repetisi pada kolom dan sebuah ramp kayu ulin menuju Lantai 1.

Berikut ini runtutan sekuens yang diambil saat kunjungan pertama untuk observasi menggunakan kamera berdasarkan arah sirkulasinya.

$$
\text { Garasi } \rightarrow \text { Gudang } \rightarrow \text { Pintu } \rightarrow \text { Inter-spasial Space } \rightarrow \ldots \rightarrow \text { Area Makan } \rightarrow \text { Ramp }
$$

Gambar di atas terdiri dari 7 adegan dalam 1 montage yang membentuk urutan pada Lt. Dasar. Dengan urutan dari paling bawah sebelah kiri sampai ke paling kanan lalu ke atas hingga ke foto paling atas sebelah kiri. Ini adalah salah satu urutan adegan yang terjadi di Lt. Dasar, penulis sebut salah satu karena pada area open plan sangat mungkin terjadi berbagai adegan yang berbeda berdasarkan pada penjelasan yang sudah dipaparkan tentang kondisi fisik Lt. Dasar di I\&L House.

Pembahasan sebelumnya merupakan contoh pembahasan yang dilakukan pada penelitian ini. Untuk selanjutnya, penulis akan lagngsung memaparkan dominasi Material Space dan Lived Space di setiap lantainya berupa grafis berskala.

\subsection{LT. 1}

Pada Lt. 1 ini hanya ruang keluarga, ruang makan, dan sirkulasi kamar yang dimasukan kedalam lembar kuesioner sebagai instrumen penelitian. Kamar tamu, anak, dan utama tidak dimasukan sebagai objek yang diteliti. Keputusan ini diambil mengingat tidak semua responden 
dapat mengakses ruangan kamar yang bersifat lebih privat dibandingkan ruangan-ruangan yang dijadikan objek dalam kuseioner.

Pada Lt. 1 ini terdapat dua ruangan yang dijadikan objek penelitan. Karena kedua ruangan tersebut merupakan ruangan-ruangan yang paling sering digunakan oleh kelima responden. Adapun ruangan tersebut adalah ruang makan dan ruang keluarga, serta sirkulasi kamar.

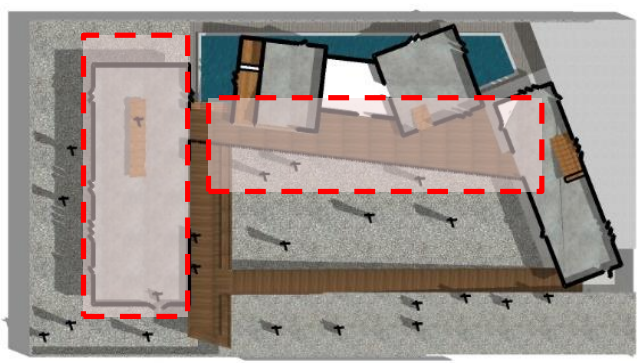

Responden mengungkapkan persepsi yang dirasakan melalui kuesioner yang mewakili kedua ruangan tersebut secara berurutan dari ruang makan dan ruang keluarga, lalu selanjutnya sirkulasi kamar. Grafik berikut adalah hasil analisa distribusi yang telah dirangkum melalui gambar grafik berskala.

\section{Dominasi Material Space dan Lived Space di R. Makan dan R. Keluarga.}

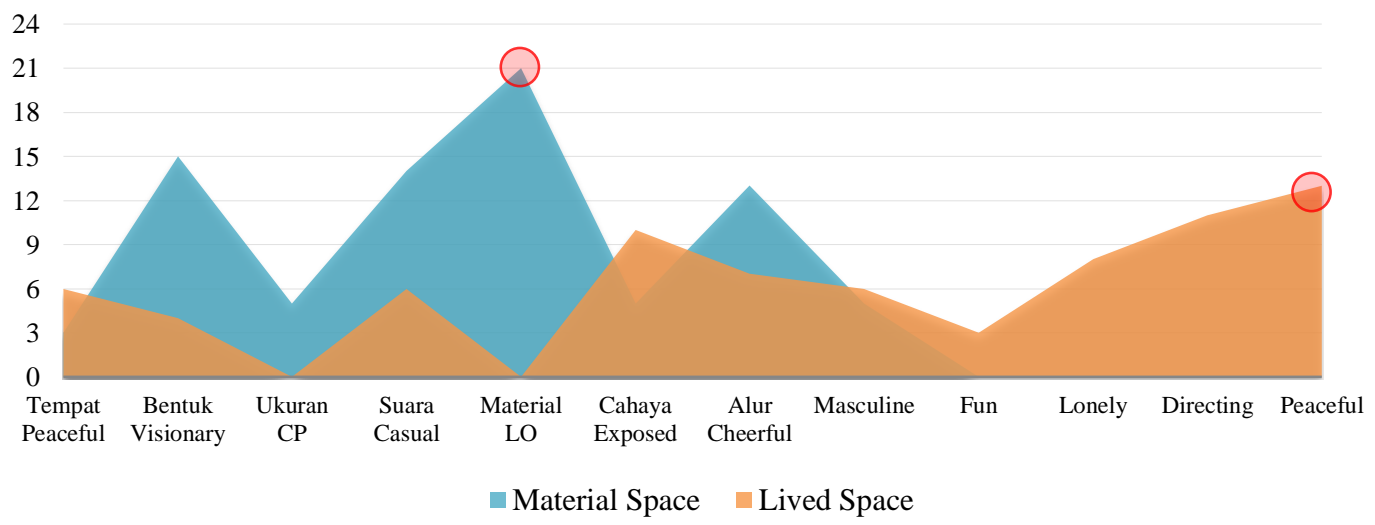

Dari gambar dominasi di atas dapat dilihat bahwa elemen Material Space dan Lived Space yang paling dominan terjadi adalah Material dan Peaceful.

\section{Dominasi Material Space dan Lived Space di Sirkulasi Kamar.}




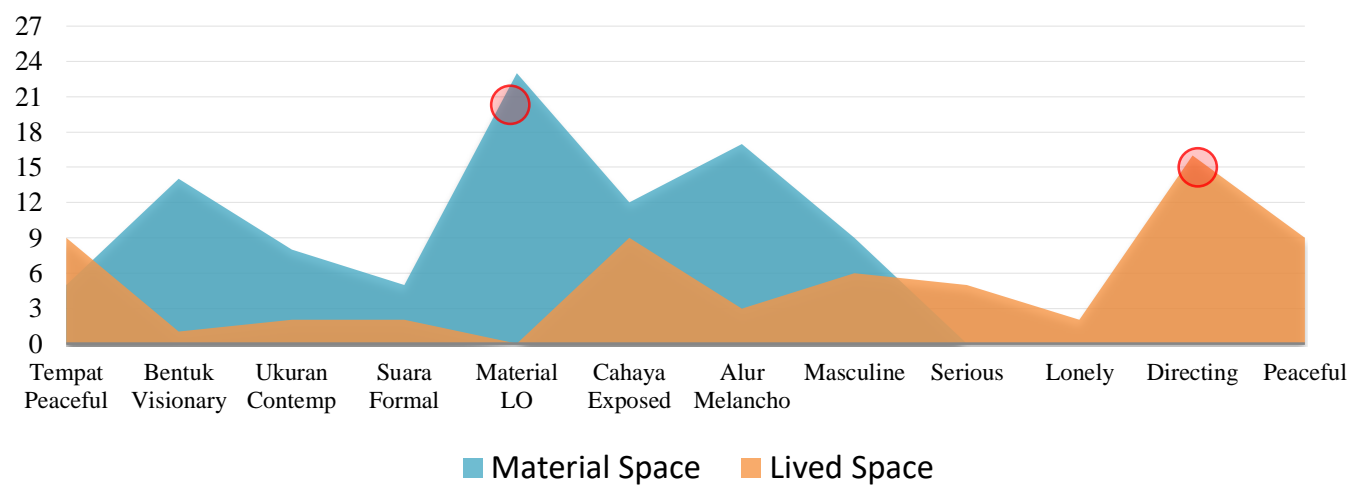

Dari gambar dominasi, di atas dapat dilihat bahwa elemen Material Space dan Lived Space yang paling dominan terjadi adalah Material dan Directing.

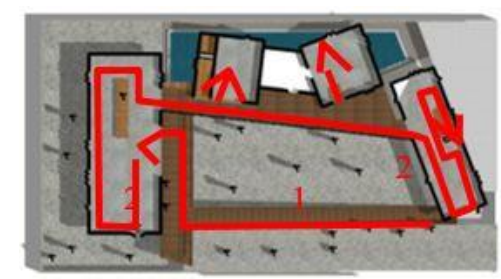

1. Continuity Montage

2. Inter-sequential Montage

Kemudian setelah melakukan observasi di Lt. 1, penulis menemukenali pola urutan yang terjadi terdiri dari dua tipe. Berbeda dengan sekuensial yang terjadi di Lt. Dasar, di Lt. 1 urutan yang terjadi terdiri dari Continuity Montage dan Trans-sequencial.

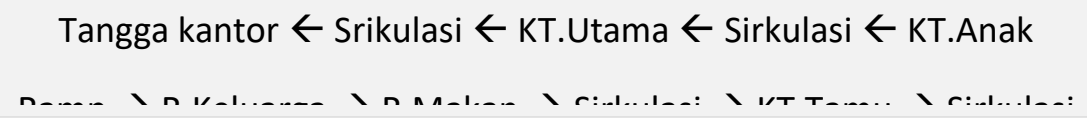

Gambar di atas merupakan rangkaian adegan yang paling mungkin terjadi pada Lt. 1. Penulis mengatakan paling mungkin terjadi karena setiap responden memiliki kegiatan masingmasing di dalam objek, sehingga rangkaian adegan yang akan dialami pun akan berbeda. Namun secara umum, rangkaian pada Lt. 1 adalah seperti di atas.

\subsection{LT. 2}

Pada Lt. 1 ini terdapat dua ruangan yang dijadikan objek penelitan. Karena kedua ruangan tersebut merupakan ruangan-ruangan yang paling sering digunakan oleh kelima responden. Adapun ruangan tersebut adalah ruang makan dan ruang keluarga, serta sirkulasi Kamar. 


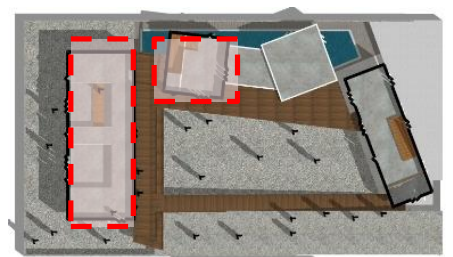

Dominasi Material Space dan Lived Space di Kantor.

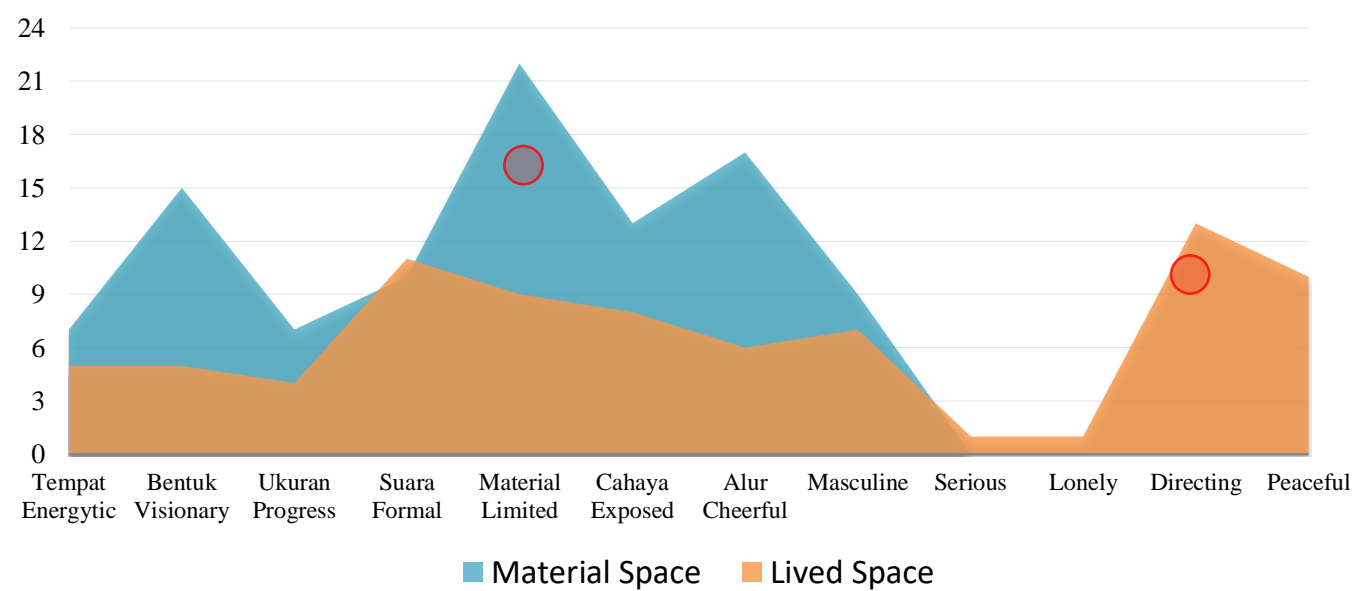

Dari gambar dominasi di atas dapat dilihat bahwa elemen Material Space dan Lived Space yang paling dominan terjadi adalah Material dan Directing.

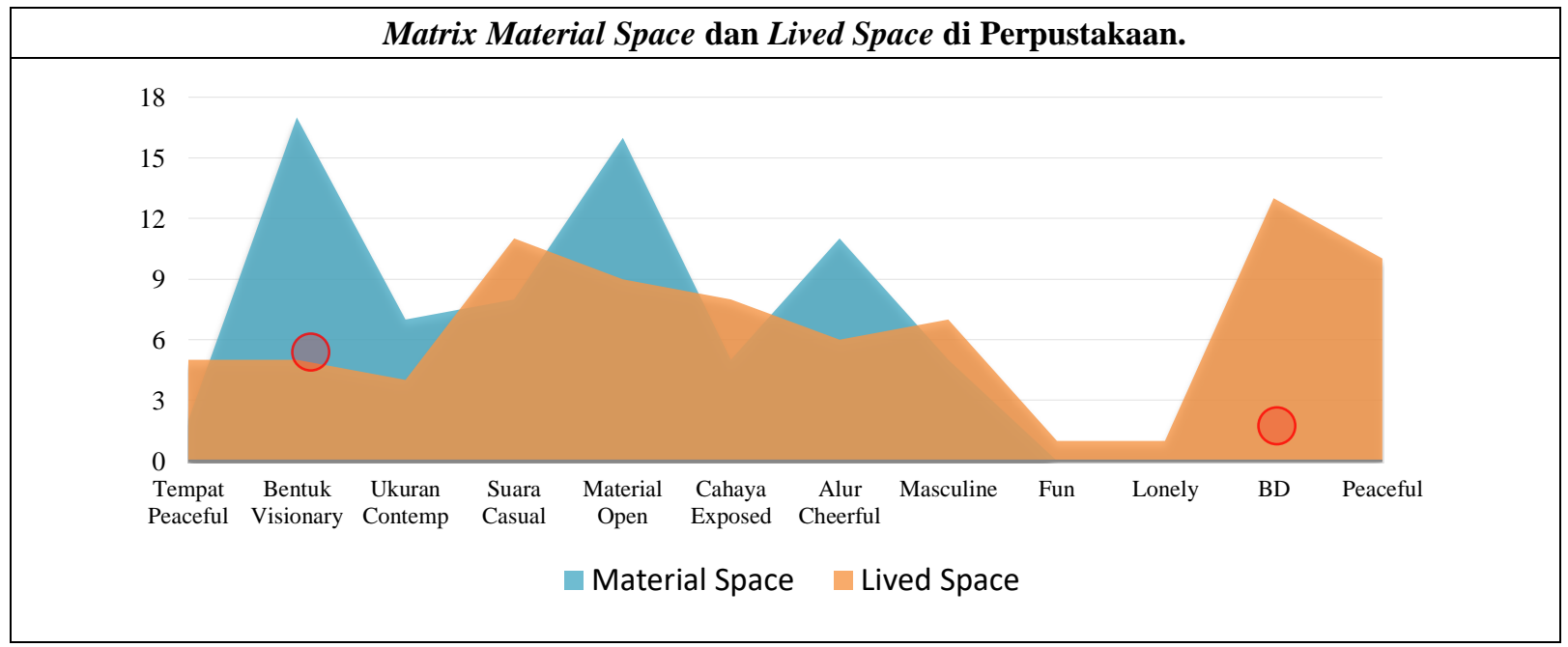

Dari gambar dominasi di atas dapat dilihat bahwa elemen Material Space dan Lived Space yang paling dominan terjadi adalah Bentuk dan Directing. 


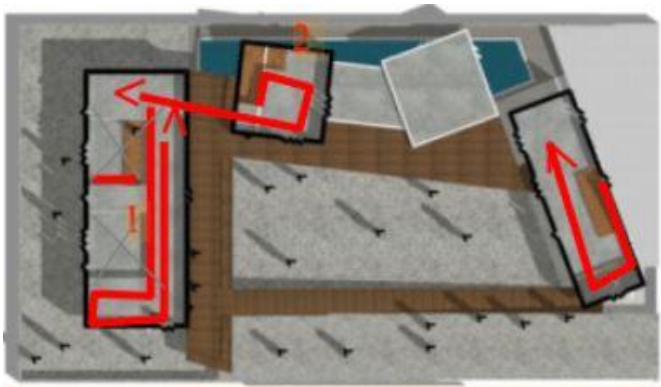

1. Trans-sequential Montage

2. Inter-sequential Montage

Rangkaian adegan yang terjadi di Lt. 2 cenderung sederhana bila dibandingkan dengan Lt. Dasar dan Lt. 1 I\&L House karena hanya terdiri dari 2 ruangan dan 2 path directing atau penghubung.

\section{Tangga Kantor $\rightarrow$ Kantor $\rightarrow$ Ruang Duduk $\rightarrow$ Perpustakaan}

Setelah melakukan distributif dengan mengakumulasikan nilai elemen Material Space di setiap ruangnya, diketahui bahwa terdapat 3 elemen yang memiliki hasil paling signifikan berpengaruh terhadap terbentuknya persepsi pada Lived Space di I\&L House secara umum, yakni:

\section{Material, Bentuk, dan Cahaya}

Yang disusul dengan Suara, Waktu, Ukuran, serta Alur dan Tempat.

Dan setelah melakukan distributif dengan mengakumulasikan nilai elemen Lived Space di setiap ruangnya, diketahui bahwa terdapat 4 elemen yang memiliki hasil paling signifikan terrpengaruh dari elemen Material Space I\&L House secara umum, yakni:

\section{Masculine, Direciting, Peaceful, dan Exposed}

\section{KESIMPULAN}

Dari proses analisis yang dilakukan terhadap Mental Space di I\&L House dapat disimpulkan bahwa bila runutan elemen Mental Space pada I\&L House membentuk pola yang tidak sama dengan banguan pada umumnya, maka pola elemen Mental Space di berbagai banguan dapat bervariasi, mengingat pola elemen Mental Space pada I\&L House terbentuk karena terjadi tumpang tindih atau overlap antara Story, Concept, dan Idea.

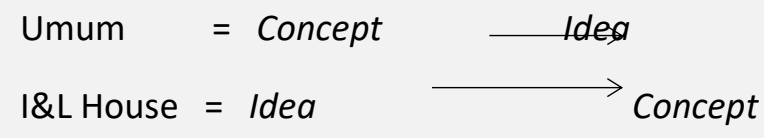

Di atas adalah runutan yang terjadi pada I\&L House berbeda dengan bangunan lain pada umumnya. Dari proses analisa terebut, penulis juga dapat menarik keimpulan bahwa perepsi hunian yang sudah ada pada alam mental pemilik dari masa lampau, dapat memengaruhi 
menentukan seperti apa bentukan dan bagaimana konsep dan ide diimplementaskan ke hunian sehingga akan dianggap menjadi hunian paling ideal untuk dimiliki.

Mental Space yang terbentuk pada I\&L House tidak seperti runutan pemunculan elemen mental space pada bangunan umumnya. Hal ini terjadi karena adanya overlaping konten elemen mental space sehingga berbagai variasi pola mental space yang memungkinkan banyak terjadi secara berbeda-beda. Kemudian satu elemen material space tidak hanya menyebabkan terbentuknya satu elemen persepsi pada Lived Space saja. Satu elemen Material Space dapat berpengaruh terhadap satu atau lebih persepsi yang diterima oleh pengguna bangunan. Begitu pun sebaliknya, satu elemen persepsi Lived Space dapat terbentuk dari beberapa elemen Material Space. Hasil analisa distribusi memperlihatkan kecenderungan persepsi pengguna pada Lived Space dari yang paling signifikan dirasakan adalah Masculine, Direciting, Peaceful, dan Exposed. Terpengaruh oleh elemen Material Space paling berpengaruh terhadap memengaruhi terbentuknya perepsi pada bangunan I\&L House adalah Material dengan hasil distribusi 98 kali, Bentuk 61 kali, Cahaya 49 kali, dan Suara 46 kali di centang dalam kuesioner sebagai tanda setuju elemen tersebut mempenngarui elemen persepsi tertentu pada ruangan tertentu.

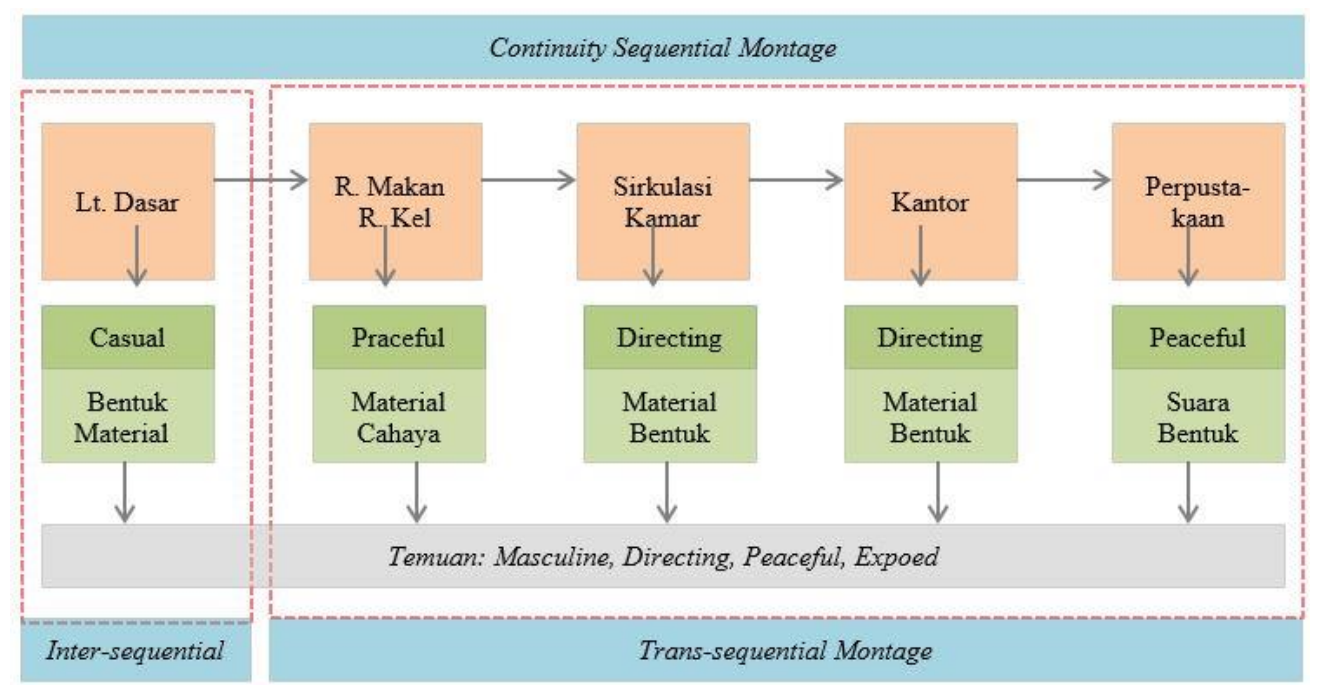

Di atas adalah sebuah gambar yang merangkum bagaimana Material dan Mental Space memengaruhi terbentuknya persepsi pengguna.

Merujuk pada bab pendahuluan, mengutip dari whiteboardjurnal.com di mana Andra Matin menyebutkan bahwa di setiap desainnya, beliau selalu menonjolkan material sebagai elemen terpenting dalam bangunan, karena kejujuran material serta seni pertemuan material (tektonika) memberikan kesan dan keindahan tersendiri. Kemudian beliau juga menyebutkan bahwa beliau sering kali mempermainkan bentuk dan tempratur pada bangunanya, karena beliau sadar bahwa kita berada di negara tropis yang memiliki suhu relatif sama sepanjang tahun.

\subsection{TEMUAN}

Melalui pendekatan yang digunakan, penulis dapat menemukenali bahwa bila keseluruan persepsi yang terbentuk di setiap ruangan dijumlah kemudian diurutkan dari paling signifikan sampai yang tidak, kemudian dipertemukan dengan hasil penjumlahan elemen material space di setiap ruangan dan diberikan peringkatya dari yang paling signifikan sampai yang tidak. Akan 
terjadi kecocokan antara Material Space dan Lived Space. Baik dari segi data maupun konten kriteria untuk setiap elemen.

Temuan: Masculine, Directing, Peaceful, Expoed

Jadi, dari kesimpulan Material Space, apa yang dimaksud beliau katakan pada wawancara oleh whiteboard jurnal berhasil tersampaikan pada I\&L House.

\section{DAFTAR PUSTAKA}

Buku

Fellows, Diane (1996), The Moving Image: Research + Design Process, Miami, Ohio.

Holl, Steven. Pallasma, Juhani. Perez-Gomez, Alberto 2006, Questions OF Perception

Phenomenology Of Architecture, San Fransisco, A+U Publishing.

Jorgensen, B. \& Stedman, R. (2001). Sense of Place as an attachment: Lakeshore owners attitudes toward their properties, Journal of Environmental Psychology, Vol. 21, pp.223 - 248.

Pallasmaa, Juhani (2001), Lived Space in Architecture and Cinema.

Canter, D. (1977). The Psychology of Place. London: Architectural Press.Cross, J.E. (2001). What is Sense of Place, Research on Place \& Space.

Stedman, R.C. (2003). Sense of Place and Forest Science: Toward a Program of Quantitative Research. Forest Science 49(6): 1- 8.

\section{Skripsi}

B, Preetika (2015), Cinema in Architecture: Synergism, Departemen of Architecture School of Architecture and Planning, Annauniversity, Chennai.

Cetin, Hasan Okan (2006), Fundamentals of Architectural Design in Comparrasion to Filmmaking, The Graduate School of Natural And Applied Sciences of Middle East Technical University.

Website

academia.edu/1934315/sensasi_dalam_ruang_arsitektur_pameran_andra_matin_sebuah_sekuel_2012. Oleh David Hutama dilihat oada tanggal 28/08/17 pukul 19.35

https://www.whiteboardjournal.com/interview/26022/ruang-yang-tidak-konvensional-bersama-andra matin/ dilihat pada tanggal 28/08/17 pukul 22.23

mediarooang.com/2014/08/menengok_kediaman_andra_matin/dilihat tanggal 29/08/17 pukul 16.01

Rachmanto, Angga 2011, "Persepsi Lingkungsn Terhadap Tata Ruang Kota"

REPOSITORY.UPI.EDU dilihat pada tanggal 13/09/17 pukul 13.03

http://widhiarso.staff.ugm.ac.id/files/3_-_semantik_diferensial.pdf/ dilihat tanggal 1/09/17 pukul 02.12

https://www.scribd.com/user/27715238/Muhamad-Zainal-Pratama dilihat pada 13/09/17 pukul 21.40 